\begin{tabular}{l} 
DUTRNAI, RISTI \\
(Rekayasa Sistem dan Teknologi Informasi) \\
Vol. 3 No.2 (2019) $297-303 \quad$ ISSN Media Elektronik: 2580-0760 \\
\hline
\end{tabular}

\title{
Aplikasi “GIZIe” Untuk Mengetahui Status Gizi Balita Menggunakan Metode Forward Chaining
}

\author{
Fiby Nur Afiana ${ }^{1}$, Ika Romadoni Yunita ${ }^{2}$ \\ ${ }^{1,2}$ Sistem Informasi, STMIK Amikom Purwokerto \\ ${ }^{1}$ fiby@amikompurwokerto.ac.id, ${ }^{2}$ ikarom@amikompurwokerto.ac.id
}

\begin{abstract}
Based on the results of Nutritional Status Monitoring (PSG) conducted by the Ministry of Health in several regions in Indonesia there are sufferers of malnutrition from the age of 0 - 59 months. Banyumas Regency itself entered into the red zone the highest number of cases of malnutrition with 65 cases. For the Baturraden area with an area of $45.35 \mathrm{~km} 2$ and having 12 villages, there is a Puskesmas which only has 1 general practitioner, 3 nurses, 6 midwives and 1 nutritionist. Based on the Recaputulation of the Agency for Health and Human Resource Development, the Health Center I Baturraden is considered still not meeting the standard number of Health Human Resources. In addition, the lack of public awareness and economic reasons further worsened the condition of community nutrition. Seeing the cases that occur requires a system that can diagnose early conditions of malnutrition in children that can be accessed directly by everyone by utilizing expert system information technology. The purpose of this study is to design and build a mobile phone (android) application called 'Gizie' by using the forward chaining method for Puskesamas 1 Baturraden Banyumas Regency which can help medical personnel and parents diagnose early malnutrition in children. The research method used is the research and development method $(R \& D)$ to produce certain products, and test the effectiveness of these products.
\end{abstract}

Keywords: malnutrition, toddler, forward chaining, gizie application

\begin{abstract}
Abstrak
Berdasarkan hasil Pemantauan Status Gizi (PSG) yang dilakukan Kementrian Kesehatan di beberapa wilayah di Indonesia terdapat penderita gizi buruk mulai usia $0-59$ bulan. Kabupaten Banyumas sendiri masuk ke dalam zona merah kasus gizi buruk tertinggi dengan jumlah 65 kasus. Untuk wilayah Baturraden dengan luas mencapai $45,35 \mathrm{~km}^{2}$ dan memiliki 12 desa, terdapat Puskesmas yang hanya memiliki 1 dokter umum, 3 Perawat, 6 Bidan dan 1 Ahli Gizi. Berdasarkan Rekaputulasi Badan PPSDM Kesehatan, Puskesmas I Baturraden dianggap masih belum memenuhi standar jumlah SDM Kesehatan. Selain itu kurangnya kesadaran masyarakat dan alasan ekonomi semakin memperburuk keadaan gizi masyarakat. Melihat kasus yang terjadi diperlukan sebuah sistem yang dapat mendiagnosis awal kondisi gizi buruk pada anak yang bisa diakses langsung oleh semua orang dengan memanfaatkan teknologi informasi sistem pakar. Tujuan dari penelitian ini adalah merancang dan membangun aplikasi mobile phone (android) bernama 'Gizie' dengan menggunakan metode forward chaining untuk Puskesamas 1 Baturraden Kabupaten Banyumas yang dapat membantu tenaga medis dan para orang tua mendiagnosis awal kondisi gizi buruk pada anak. Metode penelitian yang digunakan adalah metode penelitian dan pengembangan (Research and Development/R\&D) untuk menghasilkan produk tertentu, dan menguji keefektifan produk tersebut.
\end{abstract}

Kata kunci: Gizi Buruk, Balita, Forward Chaining, Aplikasi Gizie 


\section{Pendahuluan}

Berdasarkan hasil Pemantauan Status Gizi (PSG) yang dilakukan Kementrian Kesehatan di beberapa wilayah di Indonesia masih terdapat penderita gizi buruk mulai usia 0 -59 bulan. Salah satu kasus gizi buruk dan campak yang melanda Kabupaten Asmat sejak September 2017 hingga saat ini cukup menghebohkan masyarakat Indonesia, dimana tercatat telah merenggut 71 nyawa anak-anak. Pemerintah telah menetapkan kejadian ini sebagai Kejadian Luar Biasa (KLB) [1]. Kasus ini bisa terjadi karena beberapa faktor, kondisi geografis yang didominasi rawa berlumpur dan sungaisungai dianggap sebagai salah satu pemicu utama kasus tersebut. Kabupaten Asmat yang terdiri dari sembilan distrik (setingkat kecamatan) dan lebih dari 100 kampung. Luas kabupaten itu mencapai 29.000 kilometer persegi atau 48 kali luas DKI Jakarta, jumlah tenaga kesehatan yang dimiliki sangat tidak memadai dan tidak bisa menjangkau kampung-kampung di pelosok yang tidak memiliki akses listrik, komunikasi dan air yang mencukupi.

Kemudian bagaimana dengan wilayah lain di Indonesia? Khususnya di Kabupaten Banyumas, berdasarkan Buku Saku Kesehatan Triwulan 2 Tahun 2016 [2], Kabupaten Banyumas masuk ke dalam zona merah kasus gizi buruk tertinggi dengan jumlah 65 kasus. Kabupaten Banyumas saat ini memiliki 8 Dokter Anak, 48 Ahli gizi, 39 Puskesmas dan 22 Rumah Sakit. Dengan luas wilayah mencapai $1.327,60 \mathrm{~km} 2$ dan jumlah penduduk 1.635 .909 jiwa (https://banyumaskab.bps.go.id), jumlah tenaga dan fasilitas kesehatan kurang memadai sehingga Kabupaten Banyumas masih berada di zona merah kasus gizi buruk tertinggi di tahun 2016. Selain itu kurangnya kesadaran masyarakat dan alasan ekonomi semakin memperburuk keadaan gizi masyarakat. Kengganan orang tua karena alesan ekonomi mahalnya biaya berobat menjadi faktor utama "rasa enggan" berkonsultasi dengan dokter spesialis anak atau ahli gizi setempat. Hal ini tentu tidak dapat dibiarkan berlarut-larut karena hambatan pertumbuhan, kurang gizi, dan berat badan saat balita akan berpengaruh
terhadap perkembangan saat dewasa menjadi tidak maksimal baik dalam hal kesehatan maupun mental.

Kemajuan teknologi adalah sesuatu yang tidak bisa dihindari dalam kehidupan ini, karena kemajuan
teknologi akan berjalan sesuai dengan kemajuan ilmu pengetahuan, setiap inovasi diciptakan untuk memberikan manfaat positif bagi kehidupan manusia [3].

Dengan bantuan teknologi, diharapkan dapat memecah permasalahan yang terjadi di masyarakat [4]. Sistem pakar adalah suatu cabang kecerdasan buatan yang menggunakan pengetahuan-pengetahuan khusus yang dimiliki oleh seorang ahli untuk menyelesaikan suatu masalah tertentu [5][6]. Dirancang untuk ditampilkan pada tingkat ahli dengan tiga bagian yaitu pengetahuan dasar, mesin inferensi dan antarmuka pengguna. Mesin inferensi merupakan inti/otak/pusat dari sistem pakar, memuat mekanisme fungsi berpikir dan pola-pola penalaran sistem yang digunakan oleh pakar [7]. Forward Chaining adalah salah satu metode penalaran untuk mendapatkan kesimpulan dari fakta yang ada di lapangan [8][9]. Forward chaining disebut juga sebagai penalaran dari bawah ke atas karena penalaran dari fakta pada level bawah menuju konklusi pada level atas didasarkan pada fakta [6][8][10].

Melihat kasus yang terjadi Kabupaten Banyumas diperlukan sebuah sistem yang dapat mendiagnosis awal kondisi gizi buruk pada anak yang bisa diakses langsung oleh semua orang khususnya tenaga kesehatan. Gizi buruk adalah suatu kondisi di mana seseorang dinyatakan kekurangan nutrisi, atau dengan ungkapan lain status nutrisinya berada di bawah standar rata-rata dan dapat berakibat fatal pada kesehatan balita [11][12][13]. Oleh karena itu, dibuatlah suatu sistem berbasis Android yang dapat mendiagnosis awal kondisi gizi buruk pada anak (Gizie) dengan bantuan teknologi khususnya sistem pakar. Penelitian ini akan menggunakan metode Forward Chaining dalam pembahasannya. Salah satu penelitian yang membahas Sistem Pakar Diagnosis Gizi Buruk Pada Balita Menggunakan Metode Forward Chaining di Puskesmas Tinewati [13], menggunakan analisis pengukuran Antropometri namun tidak menggunakan usia, berat dan panjang atau tinggi anak sebagai salah satu kaidah produksi di dalam basis pengetahuan. Sama dengan penelitian lainnya yang menggunakan metode Forward Chaining untuk mendiagnosis gizi buruk, hanya menggunakan ciri-ciri fisik sebagai kaidah produksi [14] tanpa menyertakan usia, berat dan panjang atau tinggi. Berdasarkan Buku Standar Antropometri Penilaian Status Gizi, ketiga faktor tersebut memegang peranan yang sangat penting untuk menganalisis status gizi anak [15] disertai ciri-ciri pendukung lainnya.

Diharapkan aplikasi Gizie berbasis Android ini mampu membantu orang tua khususnya para Ibu di Lingkungan Puskesamas 1 Baturraden Kabupaten Banyumas untuk mencegah kondisi gizi kurang dan gizi buruk yang akan berdampak terhadap perkembangan anak saat dewasa dengan mendiagnosis lebih awal dengan melihat ciriciri selama tumbuh kembang anak.

\section{Metode Penelitian}

Subjek penelitian dalam kasus ini adalah Gizie sebagai media yang dapat membantu tenaga medis dan para orang tua mendiagnosis awal kondisi gizi buruk pada anak. Aplikasi Gizie terdiri dari beberapa tahap seperti pada gambar 1.

\section{a. Tahap Pertama}

Tahap pertama merupakan tahap perencanaan, dimana pada tahap ini dilakukan persiapan, study 
literatur dan rumusan masalah.

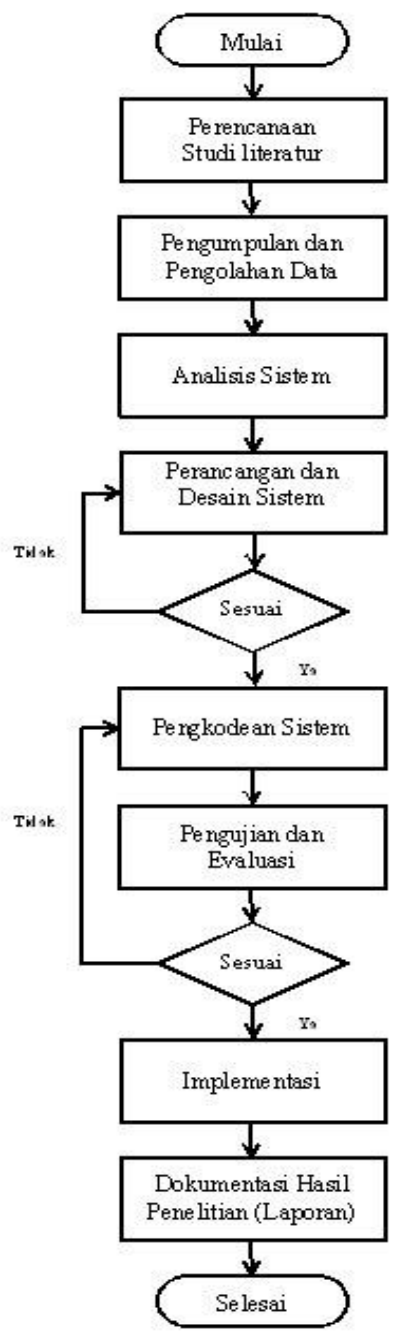

Gambar 1. Alur Penelitian

b. Tahap Kedua

Tahap kedua yaitu tahap pengumpulan data melalui observasi, wawancara dengan ahli gizi dari Puskesmas 1 Baturraden Ibu Esti Wahyuni, AMG, studi kepustakaan dan dokumentasi serta melakukan pengolahan data yang telah didapatkan. Pengumpulan data digunakan dalam memperoleh data-data yang dibutuhkan.

c. Tahap ketiga yaitu tahap analisis dan pembahasan Pada tahap analisa sistem dilakukan oleh anggota, yang kemudian perancangan dan desain system menggunakan metode Forward Chaining. Diteruskan dengan pengkodean, implementasi serta pengujian dan evaluasi terhadap sistem yang diterapkan. Aplikasi Gizie yang sudah siap akan diperkenalkan di lingkungan Puskemas 1 Baturraden dengan mengadakan pelatihan selama 3 hari.

d. Tahap Keempat

Tahap keempat yaitu tahap dokumentasi hasil penelitian.

\section{Hasil dan Pembahasan}

\subsection{Analisis Sistem}

Aplikasi gizie digunakan untuk mendiagnosis awal kondisi gizi pada anak khususnya balita dengan rentang usia 0 hingga 60 bulan (0-5 tahun). Aplikasi Gizie berbasis android memiliki sistem user friendly sehingga mempermudah para pengguna yang diperuntukkan bagi para orang tua. Dalam penelitian metode yang digunakan adalah forward chaining untuk memperoleh kesimpulan bagaimana tingkatan kondisi gizi dari balita berdasarkan ciri-ciri yang terlihat. Dalam penelitian data-data yang dikumpulkan berdasar dari buku Standar Antropometri yang dikeluarkan Kementrian Kesehatan RI [15], beberapa literature dan konsultasi dengan ahli gizi setempat diperoleh 6 tingkatan gizi balita dan 40 data ciri-ciri kondisi gizi balita.

\subsection{Data Kondisi Gizi}

Tabel 1, menunjukkan tingkatan gizi pada balita yang diperoleh untuk diterapkan dalam penelitian yang akan dilakukan.

Tabel 1. Tingkatan Gizi Balita

\begin{tabular}{cl}
\hline Kode Tingkatan Gizi & \multicolumn{1}{c}{ Nama Tingkatan Gizi } \\
\hline TG1 & Gizi Buruk Kwashiorkor \\
TG2 & Gizi Buruk Marasmus \\
TG3 & Gizi Buruk Marasmus- Kwashiorkor \\
TG4 & Gizi Kurang \\
TG5 & Gizi Baik \\
TG6 & Gizi Lebih \\
\hline
\end{tabular}

\subsection{Data Ciri-ciri}

Berdasarkan tingkatan gizi yang ada, diperoleh data ciri-ciri yang dapat dilihat pada tabel 2 .

Tabel 2. Daftar nama ciri-ciri

\begin{tabular}{ll}
\hline Kode Ciri-ciri & \multicolumn{1}{c}{ Nama Ciri-ciri } \\
\hline G01 & Usia < 60 bulan \\
G02 & Berat < $12,4 \mathrm{~kg}$ \\
G03 & Tinggi <96,1 cm \\
G04 & Pembengkakan punggung kaki \\
G05 & Muka bulat dan sembap \\
G06 & Pandangan Mata kuyu dan sayu \\
G07 & Rambut tipis, jarang, dan rapuh \\
G08 & Anemia, Diare dan disertai penyakit infeksi \\
G09 & Badan sangat kurus \\
G10 & Mudah menangis/cengeng dan rewel \\
G11 & Kulit menjadi keriput \\
G12 & Disertai penyakit infeksi \\
G13 & Diare kronik atau konstipasi \\
G14 & Tubuh mengandung lebih banyak cairan \\
G15 & Kalium dalam tubuh menurun drastis \\
G16 & Berat badan kurang dari 60 persen berat \\
& badan normal \\
G17 & Usia < 60 bulan \\
G18 & Berat < 14,1 kg \\
G19 & Tinggi < 100,7 cm \\
G20 & Tidak memiliki nafsu makan \\
G21 & Anak sangat mudah untuk marah, terlihat \\
& lesu, dan dapat menangis berlebihan \\
G22 & Munculnya gangguan penglihatan \\
G23 & Bentuk tulang kaki O atau X \\
G24 & Perkembangan intelektual dan perilaku yang \\
\hline
\end{tabular}




\begin{tabular}{ll}
\hline G25 & lambat \\
G26 & Usia $<60$ bulan \\
G27 & Tinggi $<119,2 \mathrm{~cm}$ \\
G28 & Memiliki indeks massa tubuh (IMT) yang \\
& normal \\
G29 & Kuat menghadapi serangan penyakit \\
G30 & Buang air besar teratur \\
G31 & Tubuh kuat dan kencang \\
G32 & Memiliki nafsu makan baik \\
G33 & Usia <60 bulan \\
G34 & Berat $>24,2$ kg \\
G35 & Tinggi $>119,2$ \\
G36 & Wajah bulat dengan pipi tembem dan dagu \\
& rangkap \\
G37 & Leher relatif pendek \\
G38 & Dada membusung dengan payudara \\
& membesar \\
G39 & Perut membuncit \\
G40 & Alat kelamin kecil \\
\hline
\end{tabular}

\subsection{Merancang Basis Pengetahuan Solusi} Pengendalian

Berdasarkan pengetahuan ahli gizi, Esti Wahyuni, AMG, untuk mengatasi permasalahan mengenai tingkatan gizi balita dapat dilihat pada tabel 3 .

Tabel 3. Basis Pengetahuan Solusi Tingkatan Gizi

\begin{tabular}{|c|c|c|c|}
\hline ID & $\begin{array}{c}\text { Nama Tingk } \\
\text { Gizi }\end{array}$ & Katan & Solusi \\
\hline TG1 & Gizi & Buruk & IF Gizi Buruk Kwashiorkor $O R$ \\
\hline & Kwashiorkor & & Gizi Buruk Marasmus $O R$ Gizi \\
\hline TG2 & $\begin{array}{l}\text { Gizi } \\
\text { Marasmus }\end{array}$ & Buruk & $\begin{array}{l}\text { Buruk Marasmus- Kwashiorkor } \\
\text { THEN Berikan ASI eksklusif, }\end{array}$ \\
\hline TG3 & $\begin{array}{l}\text { Gizi } \\
\text { Marasmus- } \\
\text { Kwashiorkor }\end{array}$ & Buruk & $\begin{array}{l}\text { MPASI sesuai dengan umur, } \\
\text { Berikan makanan bervariasi dan } \\
\text { seimbang, Pemberian makan } \\
\text { sesuai fase (fase stabilitasi, } \\
\text { transisi dan rehabilitasi), } \\
\text { Berikan sumpelmen (Zink, Fe, } \\
\text { Vitamin A), Segera temui ahli } \\
\text { gizi setempat, Rutin melakukan } \\
\text { penimbangan BB, TB dan } \\
\text { lingkar kepala di posyandu. }\end{array}$ \\
\hline \multirow[t]{2}{*}{ TG4 } & Gizi Kurang & & IF Gizi Kurang THEN \\
\hline & & & $\begin{array}{l}\text { Pemberian makanan dengan gizi } \\
\text { seimbang, berikan makanan } \\
\text { dalam porsi kecil, tetapi sering, } \\
\text { Berikan ASI eksklusif, Berikan } \\
\text { imunisasi lengkap, Rutin } \\
\text { melakukan penimbangan BB, } \\
\text { TB dan lingkar kepala di } \\
\text { posyandu. }\end{array}$ \\
\hline TG6 & Gizi Lebih & & $\begin{array}{l}\text { IF Gizi Lebih THEN Ajarkan } \\
\text { gaya hidup sehat, Ajak anak } \\
\text { melakukan aktifitas fisik, } \\
\text { Terapkan pola makan } \\
\text { teratur/Gizi seimbang, Hindari } \\
\text { makanan instan dan junk food. }\end{array}$ \\
\hline
\end{tabular}

\subsection{Kaidah Produksi}

Kaidah produksi dituliskan dalam bentuk IF-THEN. Berikut adalah kaidah produksi penelitian yang digunakan.

a. Gizi Buruk Kwashiorkor

IF Usia < 60 bulan (G01) AND Berat $<12,4 \mathrm{~kg}$ (G02) Tinggi < 96,1 cm (G03) AND BB/TB >
17,1 kg (G03) AND Pembengkakan punggung kaki (G04) $A N D$ Muka bulat dan sembap (G05) $A N D$ Pandangan mata kuyu dan sayu (G06) AND Rambut tipis, jarang, dan rapuh (G07) AND Anemia, Diare dan disertai penyakit infeksi (G08) THEN Gizi Buruk Kwashiorkor.

b. Gizi Buruk Marasmus

IF Usia $<60$ bulan (G01) AND Berat $<12,4 \mathrm{~kg}$ (G02) Tinggi < 96,1 cm (G03) AND BB/TB > $17,1 \mathrm{~kg}$ (G03) AND Badan sangat kurus (G09) $A N D$ Mudah menangis/cengeng dan rewel (G10) $A N D$ Kulit menjadi keriput (G11) AND Disertai penyakit infeksi (G12) AND Diare kronik atau konstipasi (G13) THEN Gizi Buruk Marasmus.

c. Gizi Buruk Marasmus- Kwashiorkor

IF Usia $<60$ bulan (G01) AND Berat $<12,4 \mathrm{~kg}$ (G02) Tinggi < 96,1 cm (G03) AND BB/TB > $17,1 \mathrm{~kg}$ (G03) AND Tubuh mengandung lebih banyak cairan (G14) AND Kalium dalam tubuh menurun drastic (G15) AND Berat badan kurang dari 60 persen berat badan normal (G16) THEN Gizi Buruk Marasmus- Kwashiorkor.

d. Gizi Kurang

IF Usia < 60 bulan (G25) AND Berat $<24,2 \mathrm{~kg}$ (G26) $A N D$ Tinggi < 119,2 cm (G27) AND Tidak memiliki nafsu makan (G20) AND Anak sangat mudah untuk marah, terlihat lesu, dan dapat menangis berlebihan (G21) AND Munculnya gangguan penglihatan (G22) AND Bentuk tulang kaki $\mathrm{O}$ atau $\mathrm{X}$ (G23) AND Perkembangan intelektual dan perilaku yang lambat (G24) THEN Gizi Kurang.

e. Gizi Baik

IF Usia < 60 bulan (G33) AND Berat $<24,2 \mathrm{~kg}$ (G34) AND Tinggi < 119,2 cm (G35) AND Memiliki indeks massa tubuh (IMT) yang normal (G28) AND Kuat menghadapi serangan penyakit (G29) AND Buang air besar teratur (G30) AND Tubuh kuat dan kencang (G31) AND Memiliki nafsu makan baik (G32) THEN Gizi Baik.

f. Gizi Lebih

IF Usia < 60 bulan (G33) AND Berat > 24,2 kg (G34) AND Tinggi > 119,2 cm (G35) (G35) AND Wajah bulat dengan pipi tembem dan dagu rangkap (G36) AND Leher relatif pendek (G37) $A N D$ Dada membusung dengan payudara membesar (G38) AND Perut membuncit (G39) AND Alat kelamin kecil (G40) THEN Gizi Lebih.

Seluruh basis pengetahuan dengan aturan (kaidah produksi) telah lengkap atau berada pada level yang akurat, maka basis pengetahuan dan kaidah produksi siap diaplikasikan menuju pembuatan mesin infrensi. Pada bagian ini aplikasi menuntun pengguna/user untuk memasukkan fakta (ciri-ciri), sehingga dapat diperoleh suatu kesimpulan (tingkatan gizi balita). Pengetahuan di dalam basis pengetahuan dan kaidah produksi menjadi dasar dari mesin inferensi. Pada 
penelitian ini, pembuatan mesin inferensi mengacu pada metode inferensi forward chaining. Penarikan kesimpulan juga berdasarkan Pengetahuan di dalam basis pengetahuan dan kaidah produksi sehingga terbentuklah pohon penelusuran, lihat Gambar 2.

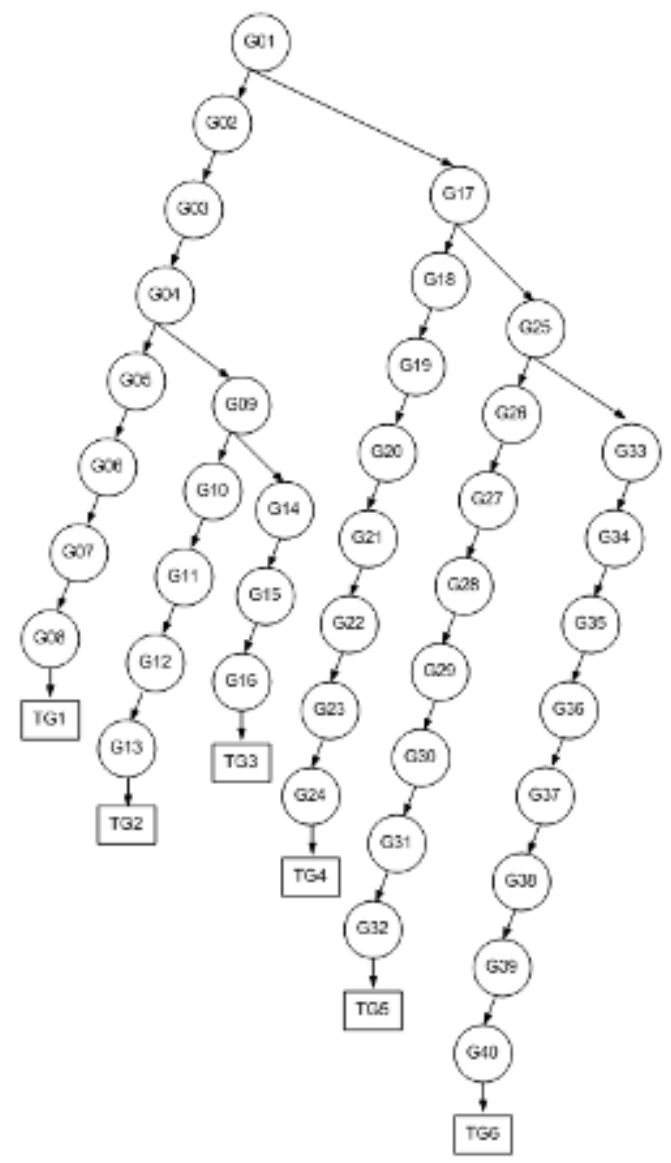

Gambar 2. Pohon Keputusan

\subsection{Implementasi Antarmuka}

Tujuan dari implementasi antarmuka untuk menggambarkan secara singkat cara penggunaan dari aplikasi Gizie.

a. Form Register

Form register ditujukan bagi orang tua balita. Untuk mempermudah penggunaan saat pertama kali melakukan pendaftaran, verifikasi tidak melalui email namun melalui no handphone karena tidak semua orang tua memiliki email yang valid. Lihat Gambar 3.

b. Form Menu Pengguna

Setelah registrasi dan login, pengguna akan masuk ke halaman utama dan dapat mengakses beberapa menu seperti Data anak, Input Data gizi anak hingga Tabel Status Gizi. Lihat Gambar 4.

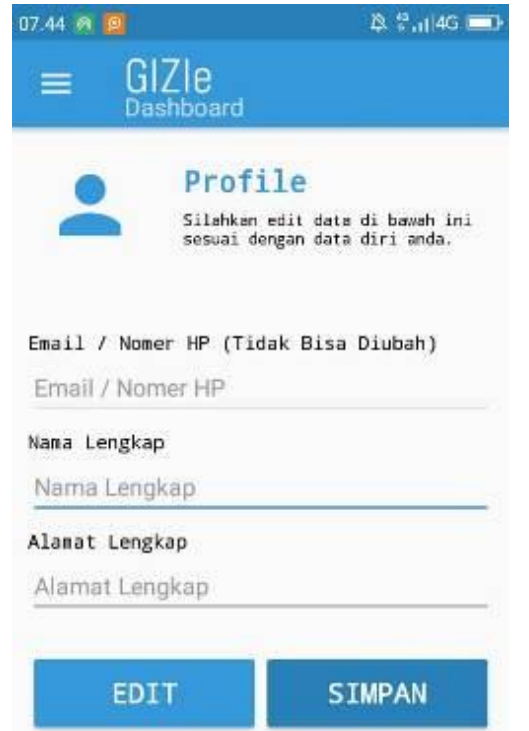

Gambar 3. Form Register

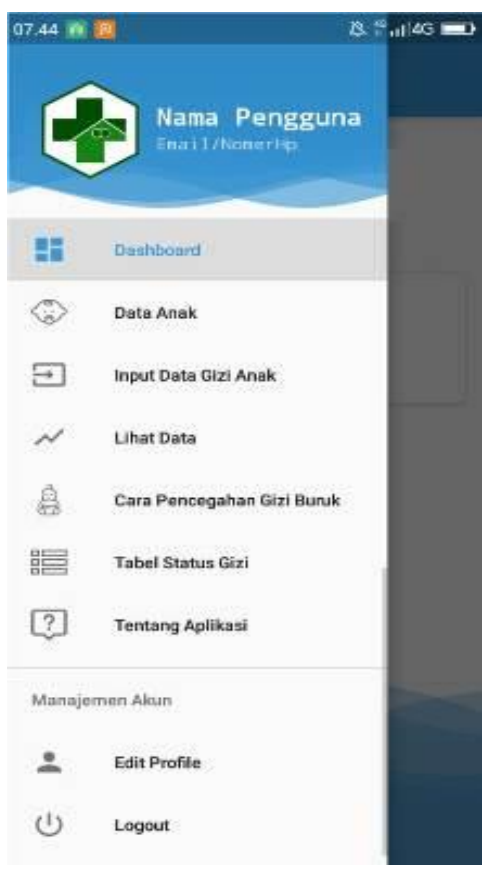

Gambar 4. Menu Pengguna

c. Form Input Data Gizi Anak

Pada halaman ini, pengguna dapat memasukkan data anak untuk mengetahui bagaimana status gizi dari balita. Basis pengetahuan yang digunakan berdasarkan pada buku Standar Antropometri. Gambar 5. Halaman Input Data Gizi Anak. 


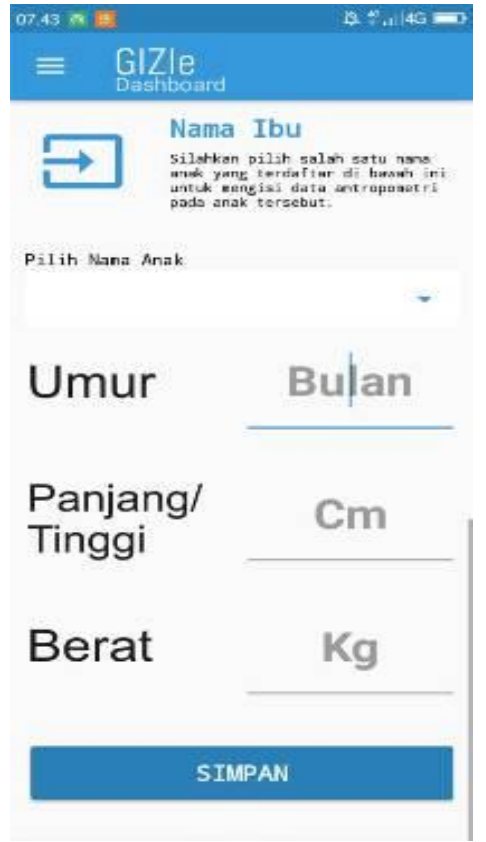

Gambar 5. Halaman Input Data Gizi Anak.

d. Form Tabel Status Gizi

Pada halaman ini, pengguna disuguhkan data berupa tabel dan grafik pertumbuhan anak tiap bulannya. Grafik yang digunakan mengacu pada grafik KMS (Kartu Menuju Sehat).

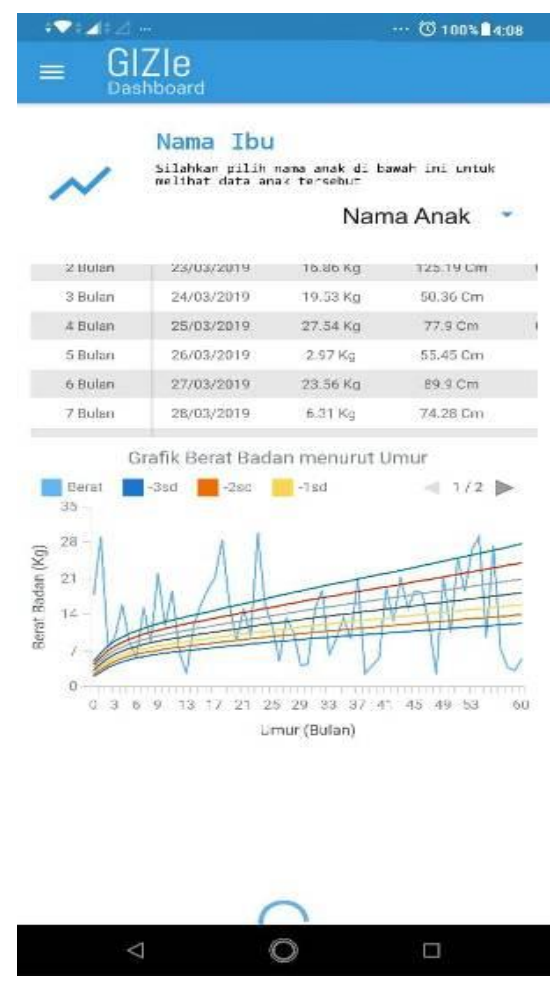

Gambar 6. Halaman Tabel Gizi Anak

\section{e. Form Login Admin}

Pada halaman ini, admin dapat melakukan login ke aplikasi. Admin dikelola oleh Ahli Gizi dari Puskesmas 1 Baturraden, yang nantinya admin dapat melihat data balita yang telah diinputkan oleh pengguna. Admin dapat memantau bagaimana perkembangan balita yang berada di wilayah Puskesmas 1 Baturraden dan bila ada balita yang berada di status gizi buruk, ahli gizi dapat segera melakukan tindakan.

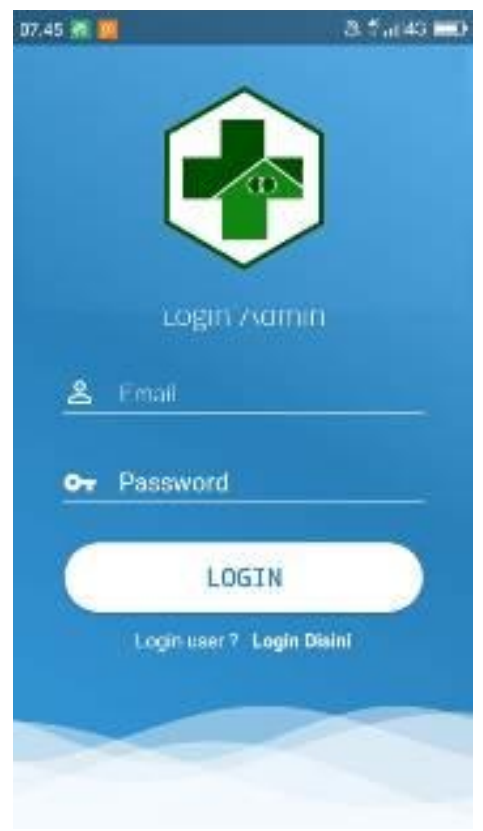

Gambar 7. Form Login Admin

\subsection{Pengujian Validasi}

Teknik untuk melihat sejauh mana kinerja dari sistem pakar khususnya metode forward chaining yang ada untuk memberikan hasil analisa pada diagnosis status gizi balita berdasarkan pada ciriciri yang terlihat dinamakan pengujian validasi [16]. Hasil rekomendasi yang didapatkan dari sistem pakar, dicocokan dengan hasil analisa dari pakar (ahli gizi). Hasil yang didapatkan dari pengujian akurasi sistem pakar ditunjukkan pada tabel 4.

Tabel 4. Pengujian Validasi

\begin{tabular}{|c|c|c|c|c|}
\hline No & Diagnosa Pakar & Diagnosis Sistem & NA & $\%$ \\
\hline \multirow[t]{2}{*}{1} & Gizi $\quad$ Buruk & Gizi $\quad$ Buruk & 1 & 100 \\
\hline & Kwashiorkor & Kwashiorkor & & \\
\hline \multirow[t]{2}{*}{2} & Gizi $\quad$ Buruk & Gizi $\quad$ Buruk & 1 & 100 \\
\hline & Marasmus & Marasmus & & \\
\hline \multirow[t]{3}{*}{3} & Buruk & Buruk & 1 & 100 \\
\hline & Marasmus- & Marasmus- & & \\
\hline & Kwashiorkor & Kwashiorkor & & \\
\hline 4 & Gizi Kurang & Gizi Kurang & 1 & 100 \\
\hline 5 & Gizi Baik & Gizi Baik & 1 & 100 \\
\hline 6 & Gizi Lebih & Gizi Lebih & 1 & 100 \\
\hline
\end{tabular}


Berdasarkan data pada tabel 4 telah dilakukan pengujian akurasi dengan 6 sampel data dari tingkatan status gizi balita dan menghasilkan nilai dari akurasi sesuai perhitungan berikut :

$$
\begin{aligned}
& \text { Nilai akurasi } \\
& \text { Jumlah data akurat } \\
& \text { Nilai Akurasi }=\frac{6}{6} \times 100 \%=100 \%
\end{aligned}
$$

Kesimpulan akurasi sistem pakar berdasarkan 6 data yang dilakukan pengujian adalah $100 \%$ menunjukkan bahwa sistem pakar Aplikasi Gizie dapat berfungsi dengan baik sesuai dengan analisa pakar.

\section{Kesimpulan}

Aplikasi Gizie dirancang dengan mengacu pada metode inferensi forward chaining. Basis pengetahuan berdasar pada buku Standar Antropometri yang diterbitkan Kementrian Kesehatan dan pakar dari Ahli Gizi di Puskesmas 1 Baturraden. Aplikasi Gizie diharapkan dapat mempermudah orang tua dan ahli gizi setempat untuk memantau status gizi dari balita yang ada di wilayah Puskesmas 1 Baturraden. Usia 0-60 bulan adalah masa "Emas" pertumbuhan otak Anak, dimana kualitas gizi akan sangat mempengaruhi pertumbuhan otak anak, sepatutnya sebagai orang tua dan stakeholder yang terlibat turut aktif dalam menjaga status gizi dari balita.

\section{Daftar Rujukan}

[1] R. Belarminus, "Ini Gambaran Menkes tentang Kondisi Korban Gizi Buruk di Asmat," https://nasional.kompas.com, 2018. [Online]. Available: https://nasional.kompas.com/read/2018/01/29/1812033 1/ini-gambaran-menkes-tentang-kondisi-korban-giziburuk-di-asmat.

[2] Dinas Kesehatan Provinsi jawa Tengah, "Buku Kesehatan Triwulan 2 tahun 2016," Dinas Kesehat. Provinsi Jawa Teng., vol. 3511351, no. 24, p. 174, 2016.

[3] M. Ngafifi, "Kemajuan Teknologi Dan Pola Hidup Manusia Dalam Perspektif Sosial Budaya," J. Pembang. Pendidik. Fondasi dan Apl., vol. 2, no. 1, pp. 33-47, 2014.

[4] I. A. Wisky and D. Saputra, "Fuzzy Logic Menganalisis Pengaruh Media Sosial Terhadap Perilaku Masyarakat
Adat Kenagarian Kinari,” J. RESTI (Rekayasa Sist. dan Teknol. Informasi), vol. 2, no. 3, pp. 639-645, 2018.

[5] Kusrini, Aplikasi Sistem Pakar Menentukan Faktor Kepastian Pengguna dengan Metode Kuantifikasi Pertanyaan. Yogyakarta: Andi Offset, 2008.

[6] Suminten and Rani, "Sistem Pakar Diagnosa Kerusakan Laptop Menggunakan Metode Forward Chaining," J. RESTI (Rekayasa Sist. dan Teknol. Informasi), vol. 2, no. 3, pp. 604-610, 2018.

[7] E. Purnamasari, K. Almisri, I. Permana, and N. Dalimunthe, "Mobile-based expert reliant system of application determining the adequacy of cows for Islamic qurban ritual using method of forward chaining," J. Theor. Appl. Inf. Technol., vol. 95, no. 11, pp. 2393-2405, 2017.

[8] A. A. Pramesti, R. Arifudin, and E. Sugiharti, "Expert System for Determination of Type Lenses Glasses Using Forward Chaining Method," Sci. J. Informatics, vol. 3, no. 2, pp. 177-188, 2017.

[9] W. Supartini, "Sistem Pakar Berbasis Web Dengan Metode Forward Chaining Dalam Mendiagnosis Dini Penyakit Tuberkulosis di JawaTimur," KINETIK, vol. 1, no. 3, pp. 147-154, 2016.

[10] K. Aeni, "Penerapan Metode Forward Chaining Pada Sistem Pakar Untuk Diagnosa Hama dan Penyakit Padi," INTENSIF, vol. 2, no. 1, pp. 79-86, 2018.

[11] A. Afritayeni, "Pola Pemberian Makan Pada Balita Gizi Buruk Di Kelurahan Rumbai Bukit Kecamatan Rumbai Kota Pekanbaru Provinsi Riau," J. Endur., vol. 2, no. 1, p. 7, 2017.

[12] D. Nababan, "Mother and Child Nutrition; ( A Review of Stunting Studies )," Mother Child Nutr., vol. 22, pp. 13-20, 2015.

[13] N. A. Evi Dewi Sri Mulyani, Deny Erwandi, "Sistem Pakar Diagnosis Gizi Buruk Pada Balita Menggunakan Metode Forward Chaining di Puskesmas Tinewati," Konf. Nas. Sist. Inform. 2015, no. Sistem Pakar, pp. 16, 2015.

[14] L. Simorangkir, N. Kahar, and D. S. Simatupang, "Sistem Pakar Untuk Mendiagnosa Gizi Buruk Pada Balita Menggunakan Metode Forward Chaining," Media Sisfo, vol. 9, no. 1, pp. 240-247, 2016.

[15] Kementrian Kesehatan, "Standar Antropometri Penilaian Status Gizi Anak," in Standar Antropometri Penilaian Status Gizi Anak, 2010, p. 40.

[16] W. D. Prasetyo and R. Wahyudi, "Sistem Pakar Diagnosis Penyakit Ternak Sapi Menggunakan Metode Forward Chaining Berbasis Website Responsif," $J$. Teknol. dan Terap. Bisnis, vol. 2, no. March, pp. 13-21, 2019. 